\title{
"Queen of the fields": Slavery's Graphic Violence and the Black Female Body in 12 Years a Slave (Steve McQueen, 2013)
}

\section{Hélène Charlery}

\section{(2) OpenEdition}

\section{Journals}

Electronic version

URL: https://journals.openedition.org/transatlantica/12453

DOI: 10.4000/transatlantica. 12453

ISSN: $1765-2766$

\section{Publisher}

Association française d'Etudes Américaines (AFEA)

Electronic reference

Hélène Charlery, "'Queen of the fields": Slavery's Graphic Violence and the Black Female Body in 12 Years a Slave (Steve McQueen, 2013)", Transatlantica [Online], 1 | 2018, Online since 12 September 2019, connection on 31 January 2023. URL: http://journals.openedition.org/transatlantica/12453 ; DOI: https://doi.org/10.4000/transatlantica.12453

This text was automatically generated on 31 January 2023

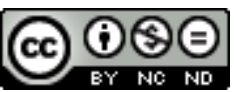

Creative Commons - Attribution-NonCommercial-NoDerivatives 4.0 International - CC BY-NC-ND 4.0 https://creativecommons.org/licenses/by-nc-nd/4.0/ 


\title{
"Queen of the fields": Slavery's Graphic Violence and the Black Female Body in 12 Years a Slave (Steve McQueen, 2013)
}

\author{
Hélène Charlery
}

1 One among at least ten prominent movies by and about black Americans released the same year, 12 Years a Slave confirmed that 2013 was "a breakout year for black films" (Cieply). ${ }^{1}$ Noting movies such as 12 Years a Slave, Fruitvale Station (Ryan Coogler), Mandela: Long Walk to Freedom (Justin Chadwick), The Butler (Lee Daniels) and 42 (Brian Helgeland), both mainstream media outlets and black-oriented news community websites endorsed the idea that 2013 marked a "black film renaissance" $(B B C)$ or a "renaissance of black cinema" (The Grio) (Penrice; Brook). The claim was later nuanced by critics such as Kellie Carter Jackson, who points out that most of these films are limited to "male-dominated or male-centered stories." Although she mentions prior exceptions such as The Color Purple (Steven Spielberg, 1985) and The Help (Tate Taylor, 2011), Jackson argues that the "peripheral" images of black women in films "subtly [send] the message that black men can play great and complex roles, while black women can continue to play marginalized roles as their girlfriends or wives." Malecentered historical narratives emphasize the active role of black men in national history while they deny black female characters historical agency and impact. Slaverythemed films in particular, from Slaves (Herbert Biberman, 1969) and Solomon Northup's Odyssey (Gordon Parks, 1984) to Amistad (Steven Spielberg, 1997) and Django Unchained (Quentin Tarantino, 2012), have firmly established the image of "the black male slave fighting for freedom" (Jackson 173-177).

2 While centering on a male character, 12 Years a Slave stands out in its treatment of slavery. In his interviews, McQueen explained that the story of a free man "who gets kidnapped and pulled into the maze of slavery [would allow] the audience [to follow] this person in every step that he takes within the context of slavery" ("12 Years"). 
McQueen thus frames his cinematic treatment of slavery in an indirect immersive experience that relies on the fact that, by the end of the film, the main character returns to his initial free status. In her review of 12 Years a Slave, French film critic Charlotte Garson calls Solomon Northup (Chiwetel Ejiofor) a "temporary" slave: the protagonist experiences slavery for a limited period of time, as the title of the movie indicates. To that extent, the film focuses on "an exception" rather than on one of "the estimated forty million who did not escape slavery" (Morris 265). Garson laments that 12 Years a Slave addresses the larger history of slavery through the story of a single exceptional individual, as if audiences were deemed "incapable of identifying with a 'real' slave, one that was born and died in slavery" (Garson 107).

Rather than assessing McQueen's strategy negatively, I suggest that Northup's double status as "temporary slave" and "exception" endows the character with the status of victim, witness of, and authority over the slave narrative that unfolds on screen. I also argue that the film's "permanent" slave is the black female supporting character Patsey (Lupita Nyong'o), a field slave who is brutalized at the hands of her master Edwin Epps (Michael Fassbender). As the Northup narrative progresses, McQueen's graphic depiction of slavery intensifies and is projected onto the black female character's narrative and body. Although she occupies a peripheral position in a male-centered narrative, Patsey is neither girlfriend, nor wife, and plays a meaningful role in the filmmaker's attempt at providing a different cinematic construction of the black experience of slavery.

\section{Northup as "temporary" slave and "exception": his story within history}

In their brief history of Hollywood treatments of plantation slavery and the slave trade, Hernán Vera and Andrew Gordon argue that Hollywood long "denied the horror of slavery by sentimentalizing it." Movies such as Gone with the Wind (Victor Fleming, 1939) and The Littlest Rebel (David Butler, 1935) are cases in point. The 1950s and early 1960s saw few direct treatments of the subject apart from Band of Angels (Raoul Walsh, 1957). The late 1960s and 1970s marked a turning point, with several "blaxploitation" films such as Mandingo (Richard Fleischer, 1975) and its sequel Drum (Steve Carver, 1976) "[driving] a stake through the heart of the plantation genre." Only in the 1990s did Hollywood turn to "more direct, serious treatments of slavery," Vera and Gordon assert, citing movies such as Jefferson in Paris (James Ivory, 1995), Amistad, and Beloved (Jonathan Demme, 1998) (Vera and Gordon 54-55). While Amistad graphically conveys the horrors of the Middle Passage, the movie-like Jefferson in Paris-ultimately focuses on the white male characters' discourse on American values. When it came out, 12 Years a Slave was logically presented as the film "no one was making"-a film based on a firsthand account of slavery, allowing viewers "to understand Solomon's psychological journey, to understand who he is, what he's endured, and in a wider sense, what people endured in that time" ("12 Years"). In Ejiofor's words, Northup's story was meant to illustrate the sufferings of a whole people and their experience of national history.

Portraying slavery in 12 Years a Slave raises the wider question of bringing slavery to the screen from a black perspective in an industry that has traditionally favored a white perspective of slavery in mainstream films. For McQueen, this implies telling the exceptional story of "one of the few victims of kidnapping to regain freedom from 
slavery," as the film's final title credit puts it. In an interview, actress Alfre Woodard, who plays Mistress Shaw in the film, states that Northup's being kidnapped into slavery is "the entrance that [...] viewers take" into slavery ("Actress"). Building on this idea, I would suggest that Northup's status as a free black man kidnapped into slavery allows contemporary audiences who are unfamiliar with the historical significance of Northup's account or other similar accounts to engage with his narrative, feel sympathy for the freeman, and empathy towards the slave.

6 Before being taken to Louisiana, Northup is put in jail in Washington, DC. The "scene in the slave pen at Washington," as it is called in the original 1853 narrative, ends with Northup screaming for help, the camera slowly moving away from his cell's window to reveal the White House in the distance. No other moment in the film illustrates more clearly the vulnerability of free blacks during slavery. The film's ending credits pay tribute to this group of people, reminding viewers that, as a black man, Northup was unable to testify "in the nation's capital" and therefore lost the case against the owner of the slave pen. Along with the film's ending credits, the scene in the slave pen illustrates McQueen's criticism of the institutions that made Northup's enslavement possible. It also dramatizes the shift from Northup the freeman to Platt the slave. ${ }^{2}$

7 Simultaneously, the Washington scene illustrates the movie's discourse on sympathy and empathy. Quoting from another critic, Salma Monani suggests that "both [sympathy and empathy] ultimately engage 'a capacity or disposition to respond with concern to another's situation." Yet Monani argues that race can be "a barrier to engaging empathetically with non-white characters" because "racial assumptions often impinge on how viewers feel concern for or with characters." Instead, circumstances of the narrative may "allow [white] viewers to be sympathetic and forgiving of the racism of white characters." For that reason, Monani claims, "many white viewers can "have trouble imagining what it is like to be African American "from the inside"-engaging black points of view empathetically"' (Monani 226-227). The Washington scene in 12 Years a Slave participates not only in Northup's construction as the author, narrator, and subject of the story that unfolds, but also in his construction as what Monani calls an "emotive agent"-an agent "with whom audience members can have feelings with or for" (Monani 226).

812 Years a Slave's opening sequence is framed between two title cards, one explaining that the film is "based on a true story," the other displaying the film's title. The first images reverse the chronology, showing Platt among the other slaves before going back to Northup before his abduction. This allows viewers to compare, through parallel editing, the two conditions the character experiences-enjoying the benefits of freedom in the North and experiencing bondage in the South. As a free black man in Saratoga in 1841, Northup puts his children to bed, then shares a moment of intimacy with his wife in the comfort of their bedroom. As an enslaved man, he has to sleep in a crowded cabin where an unknown female slave lying next to him forces her desire for intimacy upon him before bursting into tears. The film's comparative structure reinforces the contrast between Northup's life and Platt's survival. This comparison is framed within the "true story" dimension of the film and the film's title, which reinforces the temporary nature of Northup's condition and provides the audience with the reassurance that the situation of the character for whom they are asked to feel sympathy and empathy will find a positive outcome. 
The empathy/sympathy strategy also relies on the way the film defines the heroic slave. Northup's account is not that of heroic rebellion or a quest for justice, like that of Amistad's central male character Cinque (Djimon Hounsou). The rebellion that is initiated on the boat that leads Northup to the South is quickly suppressed after the black man who fomented it has been murdered. The film does not define black slave heroism the way Amistad did. In 12 Years a Slave, heroism is not romanticized rebellion, but survival, and being able to sort out the complexities of such survival. In the film's introduction, Northup is depicted as a respected citizen, a "distinguished individual," and an expert violinist. These features do not disappear as the character becomes Platt the slave. Platt is a literate black slave-Master Ford (Benedict Cumberbatch) calls him "an exceptional nigger" after he has devised a way to save costs on the transport of wood on the Ford plantation. As talented as Northup/Platt may be, however, he is subject to the same humiliating and painful use of his body and life as other slaves. As the film progresses, the elements that emphasized his distinction are used as means to further control black bodies: during the slave auction scene, Northup/Platt is summoned to play the violin so that the children's cries do not jeopardize the auction. He is also asked to perform when Master Epps whimsically wakes up exhausted slaves to have them dance late at night, or when Patsey's body, after she was hit by the carafe that Mistress Epps (Sarah Paulson) threw at her, is dragged away from the room. Northup/Platt is gradually turned into a powerless witness of, and unwilling participant in, slavery's daily atrocities. As a vehicle allowing viewers to enter the narrative, his progress into slavery sustains the audience's capacity to feel for and with him. As a filmic "exception," "one of the few victims of kidnapping to regain freedom from slavery," one of the few whose accounts could be written, his story allows for engagement. Meanwhile, it is through the eyes of the atypical temporary slave that the daily horrors and typicality of slavery, as experienced by Patsey, are displayed on screen.

\section{Patsey as "permanent" slave: her story within his/tory}

The character of Patsey is more important in McQueen's movie than it is in the original Twelve Years a Slave (Tillet). Patsey first appears on screen almost an hour into the film, when Northup is sold to Edwin Epps. Little is known about how she ended up on the Epps plantation; nor do we know what becomes of her after Northup is rescued. Garson claims that Patsey's treatment is devoid of any potential romantic construction (Garson 107). While extradiegetic music (Colin Stetson's “Awake on Foreign Shores" in particular) dramatizes Northup's journey into the South, no music accompanies Patsey's scenes. Rather, emphasis is placed on the intradiegetic natural sound of crickets chirping, which connects her with Southern landscape and imagery. When Northup is about to leave the Epps plantation, both natural sounds and Hans Zimmer's "Solomon" (the film's musical theme) can be heard as Patsey and Northup hug goodbye. As the camera focuses on Northup and Patsey faints in the distance, the sound of crickets gradually fades away while the musical theme remains and serves as a transition to the following scene on Northup's doorstep in the North.

11 As a permanent slave, Patsey is denied agency over narrative, life, and body. Contrary to Northup, her mobility is limited to the Epps plantation or to Mistress Shaw's house. Her Sunday visits to the Shaw farm provide her with much-needed respite from Epps's 
"hard countenance," but she pays the price for these visits. Whereas Northup has enough privacy at night or during the day to try and write letters to his friends in the North, Patsey is shown making corn husk dolls under the jealous gaze of Mistress Epps. McQueen carefully distinguishes between the "temporary" slave who owns his own narrative and the "permanent" slave who is seen through the gaze of others. In the original narrative, Northup is impressed by Patsey's dexterity in picking cotton: "Such lightning-like motion was in her fingers as no other fingers ever possessed, and therefore it was, that in cotton picking time, Patsey was queen of the field" (Northup 188). In the film, the same description of Patsey is used negatively by Epps: "Queen of the fields, she is. [...] Damned queen. Born and bred in the field. Nigger among niggers. And God gave her to me." This shift from Northup's voice in the text to Epps's in the film is meant to highlight Patsey's vulnerability to the white male gaze. As previously demonstrated, the film makes clear Northup's authority over his narrative. When Patsey's experience of slavery is concerned, however, Northup's authority is diminished. While Northup is unable to pick the required amount of cotton, for instance, Patsey is revealed as the top picker on the plantation. The comparison reinforces the distinction between the permanent slave who is used to picking cotton and the temporary slave who has a more recent experience of bondage on a cotton plantation.

12 In spite of these differences, Patsey is regularly associated with Northup. She first appears in the scene where Epps reads the Bible to his slaves: the camera shows her listening to Epps before panning to Northup. Though this camera move reminds viewers that this is Northup's narrative, it subtly introduces Patsey as a supporting character in his story. Likewise, the farewell scene between Northup and Patsey is as much about the end of Northup's experience of slavery as about Patsey's persistent enslavement. The focus shifts from Patsey to Northup as his carriage drives him away. In the background, Patsey, though out of focus, can be seen fainting, unnoticed by Northup; while she enters Northup's narrative rather inconspicuously, Patsey leaves it in a dramatic manner. A similar technique is previously used in Patsey's whipping scene, where the camera focuses alternately on Patsey and Northup. Thus McQueen links the two characters so that Northup's experience of enslavement on the Epps plantation is clearly informed by Patsey's own experience of permanent enslavement.

It is worth noting that 12 Years a Slave provides three enslaved women as supporting characters-Patsey, Mistress Shaw, and Eliza (Adepero Oduye)-and not a single enslaved man. McQueen focuses on the subjugation of black female bodies by white male patriarchy. Northup is made the direct witness of how these three enslaved women experience subjugation. He listens to Eliza's account of her "privileged" status as her master's favorite and subsequent downfall. He watches when she is separated from her children during the slave auction scene, and when she is forced to leave the Ford plantation. As will later be the case with Patsey, we do not know what becomes of Eliza, Northup's "last connection to his days as a free man" (Ridley 53). Eliza, however, serves as a counterpoint to another supporting character, Mistress Shaw. While the former laments what she has lost, the latter is clear-eyed about her situation:

Got no cause to worry for my sensibilities. I ain't felt the end of a lash in more years I can recall. I ain't worked the field neither. Where once I served, now I have others serving me. The cost of my current existence be Massa Shaw broadcasting his affections and me enjoying a pantomime of his fidelity. If that what keep me from cotton pickin' niggers, that what it be. 
The camera focuses on Patsey, as Mistress Shaw justifies her accommodation strategy. Her narrative then shifts to the story of her past, which is actually Patsey's present: she mentions the "lusty visit in the night" and occasional "visitation with the whip." The stories of these three enslaved women in Northup's survival account are meant to bring together their respective experiences of enslavement: Mistress Shaw has experienced the miserable life that Patsey is currently living on the Epps plantation; Eliza has experienced and lost the comfort that Mistress Shaw now enjoys; so that if Patsey's fate were to turn into Mistress Shaw's, it would remain as fragile as it was for Eliza, and as fragile as Northup's status as a free black man in the North.

12 Years a Slave alternates between scenes showing Patsey being brutalized and scenes where Northup attempts to regain his freedom. Mistress Epps's first assault on Patsey, for instance, is immediately followed by Northup's first walk to Bartholomew's, while a direct cut marks the transition between the rape scene and Northup's second visit to Bartholomew's; the close-up shot of the foolscap paper harks back to the film's opening scene, in which Northup was seen trying to write a letter using blackberry juice as ink. After the scene in which Mistress Epps viciously scratches Patsey's face, Northup goes to Willard Yarney's house to play the violin; he later promises Armsby (Garret Dillahunt) "the proceeds of [his] fiddling performances" if the latter agrees to deposit a letter in the Marksville post office. Finally, the flogging of Patsey is followed by the last conversation between Northup and Bass (Brad Pitt), which itself leads to Northup being rescued. Narratively, there are no cause-and-effect relationships between the episodes of physical abuse against Patsey and Northup's journey back to freedom. The scenes about Northup trying to regain his freedom provide respite from the increasing violence against Patsey's body. The presence of Patsey thus creates a sub-narrative of permanent bondage within Northup's narrative of temporary bondage. McQueen tells Northup's story while using Patsey as a means to depict slavery's larger history.

\section{Patsey's rape and the filmic discourse on "slavery's grotesque and relentless violence"}

Commenting on Lincoln (Steven Spielberg, 2012), historian Barbara Krauthamer explains that "the film's depiction of emancipation largely excludes African-American women and men as anything other than the patient and grateful recipients of the gift of freedom." Lincoln is unable to "come to terms with slavery's grotesque and relentless violence, especially sexual violence against black women" (Krauthamer). 12 Years a Slave narratively and graphically depicts "slavery's grotesque and relentless violence"grotesque to the extent that the violence inflicted on the enslaved is mostly due to the whims of enslavers, relentless because of its intensification throughout the movie. Although Northup is the protagonist, Patsey is the receiver of the greater share of this violence; she is given a prominent place in the film's discourse on slavery. In this last part of my essay I want to focus on the rape of Patsey. Though he shows it in a less graphic manner than her whipping, McQueen brings Patsey into a form of resistance and agency that are uncommon in other male-dominated historical films such as The Butler and Django Unchained.

The rape that takes place at the beginning of The Butler is not set under slavery but in the 1920s. Yet director Lee Daniels clearly shows a continuity between slavery and the sharecropping system that developed after the Civil War and kept African American 
families dependent on white Southerners. The rape of Hattie Pearl (Mariah Carey) occurs as the protagonist's family has just experienced a brief moment of happiness. While Hattie is being taken to a barn by the white farmer who then rapes her, her powerless husband explains to their young son that there is nothing they can do: "Come here. Look at me, boy! Don't you lose your temper with that man. This his world, we're just living in it. [...] Now get on back to work." Crucially, the rape is not shown but heard. The black cotton-pickers freeze as they hear Hattie's scream coming out of the barn. The interruption, however, is momentary. As soon as the white rapist leaves the barn, readjusting his suspenders, the black workers get back to work. Thus the film suggests that black female bodies are as vulnerable in the South in the 1920s as they were in the 1850s. But the dramatization of the rape scene is ultimately meant to support the film's focus on black fatherhood. The emphasis is on the black father's inability to protect his wife and his own life, as he is immediately shot dead when trying to confront the white farmer. The rape of the black female character in The Butler is one episode among others in the main character's psychological construction as a black father.

In Django Unchained, Broomhilda von Shaft (Kerry Washington) does not experience rape per se. Yet the brutalization of the black female body is explicit in the "hot box" scene. Broomhilda has been locked up in a hot airless box after attempting to run away; she is allowed to leave it only to be offered as a "comfort girl" to her owner's guest. Again, the scene focuses less on Broomhilda than on her male partner, Django (Jamie Foxx). As a naked and screaming Broomhilda is being retrieved from the box in which she has spent several hours, the camera lingers on Django, who is standing in front of the plantation house and looking towards the box; there are several extreme close-ups on his eyes. The brutalization of the black female's sexualized and objectified body serves to construct the protagonist's revengeful black masculinity. In both The Butler and Django Unchained, the scenes of rape and violence against women are represented as spectacular and exceptional.

While these scenes take place in broad daylight and with numerous witnesses, the rape of Patsey in 12 Years a Slave occurs in the middle of the night with only the film's viewers as witnesses. Patsey's muffled groans contrast with Hattie's and Broomhilda's piercing screams in The Butler and Django Unchained respectively. The absence of any extradiegetic music and the almost static camera force the audience to fully experience the horror of what is happening on screen. Although a single shot of Northup lying on his mat suggests that he might be aware of what is happening, Patsey's experience as a permanent slave seems to be fully dissociated from his experience as a temporary slave at this point. Northup's story is about knowing the pain inflicted on enslaved women; Patsey's is about experiencing it.

19 The rape scene in 12 Years a Slave leaves it to the viewers to understand that Patsey's body is both vulnerable and resistant in its own, passive way. Patsey's lack of reaction and empty eyes first convince Epps that she is dead, and then infuriate him to the point that he brutally slaps her and chokes her. As Epps leaves the scene, the camera shows Patsey breathing again, as if regaining life. Here McQueen distances himself from the traditional model of "sentimental vulnerability" which

sees women as especially vulnerable to pain and injury, and reads pain and injury as debilitating to the female subject. [...] This traditional model asks us as viewers to reserve our greatest sympathy for the suffering female body. (Hagelin 3 ) 
Although quite real, pain and injury are not "debilitating" in Patsey's case. While the rape of Hattie and the murder of her husband in The Butler leave her in a debilitated state, Patsey decides to orchestrate her own death, begging Northup to kill her: "End my life. Take my body to the margin of the swamp. Take me by the throat. Hold me low in the water until I's still'n without life. Bury me in a lonely place of dyin'." Patsey is shown trying to keep control over her own body, if only to destroy it. Northup's uncomprehending response to her pleading furthers the dissociation between the two characters. Because in 12 Years a Slave heroism is survival, Northup's status as a male lead is not built upon his capacity to save the black female supporting character, but on his ability to survive enslavement for twelve years, return to his family, and write about his life as a slave. Yet in the final part of the movie McQueen focuses less on the protagonist's (fruitless) quest for justice than on Patsey's efforts at gaining agency over her body, even when she "got no comfort in this life."

Thus 12 Years a Slave centers on its male protagonist as an entry point to the horrors of slavery, but it does not marginalize female roles-those of Patsey, Eliza, and Mistress Shaw. Northup's temporary journey into slavery opens a window onto the world of black enslaved women, highlighting their exploitation and surviving strategies.

\section{BIBLIOGRAPHY}

“12 Years a Slave Was a Film that 'No One Was Making."” National Public Radio, 24 October 2013. Accessed 30 December 2015.

“Actress Alfre Woodard on Truthful Storytelling in 12 Years a Slave." National Public Radio, 3 March 2014. Accessed 30 December 2015.

“Black Female Voices: Who Is Listening." Public dialogue between bell hooks and Melissa HarrisPerry. The New School, 8 November 2013. Accessed 30 December 2015.

BROOK, Tom. “A Renaissance of Black Cinema?” British Broadcasting Corporation, 21 October 2014. Accessed 30 December 2015.

CIEPLY, Michael. "Coming Soon: A Breakout Year for Black Films.” New York Times, 1 June 2013. Accessed 30 December 2015.

GARSON, Charlotte. "12 Years a Slave." Études. Revue de culture contemporaine, February 2014, p. 105-112.

HAGELIN, Sarah. Reel Vulnerability: Power, Pain, and Gender in Contemporary American Film and Television. New Brunswick: Rutgers University Press, 2013.

JACKSON, Kellie Carter. “'Is Viola Davis in it?': Black Women Actors and the 'Single Stories' of Historical Film.” Transition, no. 114, 2014, p. 173-184.

KRAUTHAMER, Barbara. “Slavery's Grotesque and Relentless Violence.” The Chronicle of Higher Education, 4 December 2012. Accessed 30 December 2015. 
MONANI, Salma. "Evoking Sympathy and Empathy: The Ecological Indian and Indigenous EcoActivism." Moving Environments: Affect, Emotion, Ecology, and Film. Ed. Alexa Weik von Mossner. Waterloo, ON: Wilfrid Laurier University Press, 2014, p. 225-248.

MORRIS, Nigel. The Cinema of Steven Spielberg: Empire of Light. London: Wallflower, 2007.

NORTHUP, Solomon. Twelve Years a Slave: Narrative of Solomon Northup, a Citizen of New-York, Kidnapped in Washington City in 1841, and Rescued in 1853, from a Cotton Plantation Near the Red River, in Louisiana. Auburn: Derby and Miller, 1853.

PENRICE, Ronda Racha. “A Black Film Renaissance, or a Step Backward for Black Actors?"

TheGrio.com, 4 October 2013. Accessed 30 December 2015.

RIDLEY, John. 12 Years a Slave. Screenplay. 2012.

TILLET, Salamishah. “'I Got No Comfort in This Life': The Increasing Importance of Patsey in 12 Years a Slave." American Literary History, vol. 26, no. 2, 2014, p. 354-361.

VERA, Hernán, and Andrew M. GORDON. Screen Saviors: Hollywood Fictions of Whiteness. Lanham: Rowman \& Littlefield, 2003.

\section{NOTES}

1. The author wishes to thank Hilary Sanders for kindly and attentively reading an earlier version of this article.

2. On this scene, see also Anne Marie Paquet-Deyris's contribution to this issue.

\section{ABSTRACTS}

This paper examines Steve McQueen's strategy in 12 Years a Slave, which consists in filming the horrors of slavery through a narrative construction that mostly concerns Solomon Northup, a "temporary" slave who survives slavery, and a visual construction centered on Patsey, a "permanent" slave who is born and dies in slavery. This double construction allows viewers to get "into" and "out of" the history of slavery, without reproducing some of the problematic patterns that previous slavery-themed films have allowed.

Cet article étudie la stratégie mise en œuvre par le réalisateur de 12 Years a Slave. Celle-ci consiste à filmer les horreurs de l'esclavage à travers une construction narrative portant principalement sur Solomon Northup, un esclave "temporaire " qui survit à l'esclavage, et une construction visuelle centrée sur Patsey, une esclave "permanente» qui vit et meurt en esclavage. Cette double construction permet aux publics du film « d'entrer » dans l'histoire de l'esclavage et d'en "sortir", sans reproduire certains schémas problématiques que les films sur l'esclavage ont jusqu'alors permis. 
INDEX

Keywords: 12 Years a Slave, Steve McQueen, slavery, race, slave narrative, gender, women

Mots-clés: 12 Years a Slave, Steve McQueen, esclavage, questions raciales, récit d'esclave, genre, femmes

AUTHOR

HÉLÈNE CHARLERY

Université Toulouse-Jean Jaurès 